\title{
Effect of Septoria leaf blotch and its control with commercial fungicides, on arbuscular-mycorrhizal-fungal colonization, spore numbers, and morphotype diversity
}

\author{
Santiago Schalamuk 1,2,5*, Silvana Velazquez ${ }^{2,5}$, María Rosa Simón ${ }^{1}$, Marta Cabello ${ }^{3,4}$

\begin{abstract}
${ }^{1}$ Facultad de Ciencias Agrarias y Forestales, UNLP, 60 y 119 (1900), La Plata, Buenos Aires, Argentina
${ }^{2}$ Consejo National de Investigaciones Cientificas y Técnicas (CONICET), Rivadavia 1917, (C1033AAJ), Buenos Aires, Argentina

${ }^{3}$ Instituto de Botánica Spegazzini, Facultad de Ciencias Naturales y Museo, UNLP, 53 \# 477 (1900), La Plata, Buenos Aires, Argentina ${ }^{4}$ Comisión de Investigaciones Cientificas de la Provincia de Buenos Aires (CICPBA), 526 entre 10 y 11 (1900), La Plata, Argentina ${ }^{5}$ CEQUINOR (CCT-La Plata-CONICET-UNLP), 47 y 115 (1900), La Plata, Argentina
\end{abstract}

Received: November 12, 2013

Accepted: January 14, 2014

\begin{abstract}
Arbuscular-mycorrhizal internal structures (i.e. total root colonization, arbuscules, vesicles) and external structures (i.e. spore density), and Glomeromycota spore morphotypes, were evaluated in wheat severely infected with Mycosphaerella graminicola - the causal agent of Septoria leaf blotch. Plots in which the infection was controlled with a commercial fungicide at recommended field doses, were also examined. The commercial fungicide used was an admixture of trifloxistrobin and tebuconazole. No negative effects of the fungicide application on arbuscular-mycorrhizal fungi (AMF) were found. The M. graminicola fungicidal treatment actually favoured the formation of arbuscules and AMF spores, as there was a selective increase in the density of spores belonging to the glomoid morphotype. Arbuscular-mycorrhizal fungi have an absolute dependence on the carbon provided by the plant. A severe foliar disease leading to a diminished carbon supply to the roots would generate decreases in carbon availability. Such decreases would strongly affect mycorrhizal associations and development. Furthermore, the change in the green-leaf area produced by a severe foliar disease and/or a reversal of that condition through fungicide treatment could result in shifts in the composition of the AMF community so as to favour glomoid morphotypes. Glomoid species have been previously considered as $r$-strategists.
\end{abstract}

Key words: Glomeromycota, Mycosphaerella graminicola, strobilurin, triazole, wheat

\section{Introduction}

Arbuscular-mycorrhizal fungi (AMF), belonging to the phylum Glomeromycota (Schüßler et al. 2001), are biotrophic fungi that form associations with most cultivated plant species. These fungi are, therefore, significant components of agroecosystems (Smith and Read 2008). In this symbiotic relationship, the fungi acquire their entire carbon supply from the plant. The colonization of roots by the AMF confers a wide range of benefits to the plant. Such benefits are an increase in nutrient uptake from the soil (Hodge et al. 2010) and an improvement in the plant's resistance to and/or tolerance to biotic stresses, particularly with respect to soil-borne diseases (Whipps 2004; Pozo et al. 2009). Arbuscular-mycorrhizal fungi can also provide long-term benefits to agroecosystems by increasing the degree of soil-carbon sequestration and the amount of organic matter (Verbruggen et al. 2013).

Foliar diseases produced by fungi cause major biotic limitations in the yield and quality of wheat. Leaf blotch, caused by Septoria tritici Rob. ex Desm. (teleomorph Mycosphaerella graminicola (Fuckel) Schroeter, in Cohn) is a serious disease in many wheat-producing areas of the world causing major decreases in crop yields (Eyal et al. 1985, 1987; Simón et al. 2002; Mojerlou et al. 2009).

The control of fungal diseases in modern agriculture usually involves the use of fungicides. The effects of fungicides on non-target organisms, such as AMF, are of principal interest to agriculture. An inhibition of the effects of beneficial organisms would counteract the advantages derived from the disease control. The impact of fungicides on AMF associations depends on multiple conditions: the chemical's formulation, mode of action, and spectrum of activity along with the application methods used (Diedhiou et al. 2004; Zocco et al. 2008; Calonne et al. 2012). Consequently, no generalization can as yet be made as to the effects of fungicides on the status of the AMF.

The effects of fungicides on AMF have been evaluated mostly in the laboratory in the absence of pathogens. In the laboratory, in vitro studies were done where AMF structures were in direct contact with the compounds e.g. monitoring spore or sporocarp germination and mycelial growth in Petri dishes or in monoxenic cultivation with transformed roots (Giovannetti et al. 2006; Campagnac et al. 2008, 2009; Zocco et al. 2008; Calonne et al. 2012). The 
effects of fungicides on AMF were also studied in greenhouse experiments in pots by applying different fungicides to plants inoculated with AMF but these were plants not affected by fungal diseases (Kjoller and Rosendahl 2000; Diedhiou et al. 2004). Few studies have been carried out in field situations to examine the effect on AMF of foliar disease control by fungicides (Land et al. 1993).

Since the supply of carbon regulates arbuscular-mycorrhizal development, we speculated that maintenance of the green-leaf area through the application of a fungicide would promote AMF symbiosis, provided that the fungicide used did not affect the AMF per se. Conversely, an untreated severe foliar disease would inhibit that process.

A knowledge of AMF functional diversity is essential for the management of these fungi in agricultural systems (Verbruggen and Kiers 2010). A number of studies have shown that Glomeromycota taxa may have different lifehistory strategies (Sieverding 1991; Morton et al. 1993; Bever et al. 2001; Franke-Snyder et al. 2001; Lovelock et al. 2003; De Souza et al. 2005; Chagnon et al. 2013). Thus, fluctuations in carbon availability, caused by reductions in the green-leaf area through a severe foliar disease and/or the reversal of that pattern as a result of disease control, could affect the various Glomeromycota taxa in a differential fashion so as to lead to shifts in the AMF community.

In this study, our first aim was to compare the AMF internal structures (i.e. root colonization, entry points, internal mycelium, arbuscules, vesicles) and external structures (i.e. spore density) along with the Glomeromycotaspore morphotypes formed in wheat that had been severely affected by M. graminicola. Our second aim was to examine for comparison purposes, those plots where the disease had been controlled with a commercial fungicide at the recommended field doses.

\section{Materials and Methods}

A field trial conducted at the Experimental Station J. Hirschhorn, School of Agricultural and Forestry Sciences, National University of La Plata was planted on 11 June 2011. The experiment had a completely randomized factorial design with three replications. The wheat cultivar used was ACA 801. The factors investigated were the fungicide/inoculation treatments and the three growth stages sampled. The plots cultivated $(1.40 \mathrm{~m}$ wide $\times$ $\times 5.50 \mathrm{~m}$ long) were sown with a conventional experimental drill at a row spacing of $20 \mathrm{~cm}$ and a seeding rate of 300 seeds $/ \mathrm{m}^{2}$. The protocols of the application with the fungicide-inoculation were: (1) inoculation with an admixture of three virulent isolates of $M$. graminicola, and (2) no inoculation but a treatment with the fungicide Nativo ${ }^{\circledR}$ (trifloxistrobin $50 \mathrm{~g}$ and tebuconazole $25 \mathrm{~g}$ ) at a rate of $600 \mathrm{~cm}^{3}$ of the product in 1501 water/ha applied from growth stage (GS) 22 every 15-20 days until physiologic maturity. The inoculated M. graminicola isolates were from the collection of the School of Agricultural and Forestry Sciences. The pathogens had been previously grown on malt extract agar at $20-22^{\circ} \mathrm{C}$ with 12 -hour alternating light and dark cycles. The inoculum was prepared by scraping sporulating colonies aseptically with a scalpel into deionized water and adjusting the conidial suspension to a concentration of $8.5 \times 10^{6}$ spores $/ \mathrm{ml}$. The plants were sprayed with the fungal suspension until runoff of the fluid. After inoculation, the plants were kept moist by sprinkling them with water several times a day for a period of 3 days.

The plants were fertilized with $50 \mathrm{~kg}$ of $\mathrm{N}$ as urea plus $50 \mathrm{~kg}$ of $\mathrm{P}_{2} \mathrm{O}_{5}$ as calcium triple superphosphate/ha at sowing, followed by $50 \mathrm{~kg}$ of N/ha as urea at tillering (GS 23, Zadoks et al. 1974). The herbicide Misil ${ }^{\circledR}$ (methylmetsulfuron: dry, flowable, $60 \%$ + Dicamba soluble liquid, $57.1 \%$ Dupont, Rosario, Argentina) at $100 \mathrm{~cm}^{3}$ in 1201 water/ha was applied at the three-leaf stage.

Samples of roots and rhizospheric soil were collected when the wheat plants reached GS 39, GS 60, and GS 82. Septoria leaf blotch severity was visually estimated as a necrotic lesion percentage (Simón et al. 2003) for the same GSs with all the green leaves of 10 plants in each plot. The area under the disease-progress curve was calculated with the data from the last three growth stages to summarize disease progression, according to Shaner and Finney's formula (1977). Composite random (Dick et al. 1996) root and soil samples were collected at a $15-\mathrm{cm}$ depth at each GS evaluated. In each instance, 5 to 6 subsamples (250 g) were collected from a given plot and then pooled. In the laboratory, the roots and rhizospheric soil were separated. The roots were processed immediately and the soil was placed in storage at $4^{\circ} \mathrm{C}$ for subsequent determinations.

Colonization by AMF was determined by clearing and staining the roots (Phillips and Hayman 1970). The different intraradical fungal structures, such as entry points, internal mycelium, arbuscules, and vesicles were observed by microscopy. The percentages of each structure were estimated through the methodology according to McGonigle et al. (1990). The spores of AMF were isolated from 100-g soil samples by wet-sieving and decanting (Gerdemann and Nicolson 1963). The spores were then transferred onto a sucrose solution for centrifugation according to the method used by Walker et al. (1982). Only those spores that appeared healthy by directly observing them under a stereomicroscope, were counted in a 9-cm Petri dish. The AMF-spore counts are expressed as the number of spores per $100 \mathrm{~g}$ dry soil. The soil-moisture content was calculated for each soil sample as a per cent of the wet weight of soil, after drying at $80^{\circ} \mathrm{C}$ for $48 \mathrm{~h}$ in an oven and then reweighing.

For morphotype identification, spores were extracted and mounted on slides with polyvinyl alcohol/lactic acid/ glycerol (Koske and Tessier 1983) or in a mixture of those three and Melzer's reagent (1:1, v/v; Blaszkowski et al. 2009). The spores obtained after sieving, decanting, and centrifuging were then classified according to the morphotypes glomoid, acaulosporoid, and gigasporoid on the basis of their morphologic features (Oehl et al. 2011).

Data were analyzed by the analysis of variance (ANOVA) for factorial designs using Genstat Release 12.1 (2009). The factors included were the inoculation and fungicide treatment, the growth stage, and the Glomeromycota morphotype. 


\section{Results and Discussion}

The analysis of variance indicates that fungicide application significantly affected Septoria leaf blotch severity (Table 1). The M. graminicola-inoculated plots displayed high severities of infection $(55.7 \%$ on the average over the three growth stages, Table 2). The Septoria leaf blotch increased significantly in severity during the crop's growth cycle, and was markedly and significantly reduced (by $39.2 \%$, Table 2) with the application of the fungicide. Consequently, the area under the disease-progress curve was reduced by the fungicide treatment (to 1,513 vs. 2,839 units $^{2}$; data not shown).

All the evaluated internal mycorrhizal structures (i.e. entry points, internal mycelium, arbuscules, and vesicles) along with the external structures (i.e. AMF spores) were affected by the crop-growth stages (Table 1). Significant interactions for fungicide-growth stage were found for arbuscule percentages and total AMF spore numbers. With the fungicide treatment, the former of those parameters was higher at GS 60 (flowering) and the latter at GS 82 (grain filling) than the respective values from the untreated plots (Table 3). That difference in the percentage of arbuscules found at flowering is reasonable since that parameter increases until anthesis but then declines at the end of the growing season (Schalamuk et al. 2004). The decrease in arbuscules in wheat at that time can be attributed to the reduction in the supply of carbon from photosynthesis to the roots that occurs during grain ripening (Mohammad et al. 1998).

No deleterious effects on the AMF were observed after fungicide application. In fact, the control of M. graminic- ola favoured the formation of mycorrhizal structures. We propose that fungicide applications may affect AMF associations; directly by an action on the Glomeromycota fungi themselves or indirectly through changes in plant physiology derived from the reduction of the disease in the host plant. It should be taken into account that AMF are greatly affected by the physiological status of the plant since they are biotrophic microorganisms (Smith and Read 2008).

In the present study, a direct effect of fungicide application on the AMF could not be demonstrated. A comparison of mycorrhizal development in the plots with fungicide treatment with that from disease-free wheat without fungicide application, would have been necessary. In greenhouse conditions, a disease-free treatment without applying fungicides can be achieved. In the field, though, in the absence of a fungicide application, infection by spores within natural ambience, which is at least to some extent random, is inevitable. Previous studies in greenhouses, however, had already demonstrated that fungicides belonging to the strobilurins and triazoles at recommended doses, do not affect mycorrhization in crop plants (Schweiger and Jakobsen 1998; Kjoller and Rosendahl 2000; Diedhiou et al. 2004). Tebuconazole is a systemic fungicide (Homdork et al. 2000), while trifloxystrobin is mesostemic (Parvatha Reddy 2013). Nevertheless, even with fully systemic fungicides within the plant tissues, AMF do not come into direct contact with the pesticide. The reason is that all of those compounds are translocated acropetally into the leaves and the shoot tip. The low, or the entirely absent, basipetal transport of tebuconazole and trifloxystrobin, may help to explain

Table 1. Analysis of variance for Septoria leaf blotch severity and mycorrhizal structures (entry points, internal mycelium, arbuscules, vesicles and spores) on a wheat crop with and without fungicide at three growth stages

\begin{tabular}{lccccccc}
\hline \multicolumn{1}{c}{$\begin{array}{c}\text { Source of } \\
\text { variation }\end{array}$} & df & Severity & Entry point & $\begin{array}{c}\text { Internal } \\
\text { mycelium }\end{array}$ & Arbuscules & Vesicles & AMF spores \\
\hline Fungicide & 1 & $2156.5(0.001)^{*}$ & $355.6(0.235)$ & $32.4(0.602)$ & $265.78(0.014)$ & $348.19(0.068)$ & $84.5(0.510)$ \\
Growth stage & 2 & $8630.7(<0.001)$ & $5881.6(<0.001)$ & $4437.7(0.001)$ & $2479.28(<0.001)$ & $1148.77(<0.001)$ & $928.2(0.029)$ \\
$\begin{array}{l}\text { Fungicide } \times \\
\text { growth stage }\end{array}$ & 2 & $103.9(0.451)$ & $93.1(0.673)$ & $43.7(0.687)$ & $160.46(0.026)$ & $214.04(0.127)$ & $1066.2(0.020)$ \\
$\begin{array}{l}\text { Residual } \\
\text { Total }\end{array}$ & 12 & 122.0 & 227.2 & 112.8 & 32.02 & 86.84 & 180.9 \\
\hline
\end{tabular}

AMF - arbuscular-mycorrhizal fungi; ${ }^{*} \mathrm{p}>\mathrm{F}$, Fisher test

Table 2. Mean values for Septoria leaf blotch severity, entry points, internal mycelium, and vesicles on a wheat crop with and without fungicide at three growth stages

\begin{tabular}{|c|c|c|c|c|}
\hline Treatments & $\begin{array}{c}\text { Severity } \\
{[\%]}\end{array}$ & $\begin{array}{c}\text { Entry point } \\
{[\%]}\end{array}$ & $\begin{array}{c}\text { Internal mycelium } \\
{[\%]} \\
\end{array}$ & $\begin{array}{c}\text { Vesicles } \\
{[\%]} \\
\end{array}$ \\
\hline \multicolumn{5}{|l|}{ Growth stage } \\
\hline GS 31 & $13.9 \mathrm{c}$ & $18.3 \mathrm{c}$ & $40.4 \mathrm{~b}$ & $12.6 \mathrm{~b}$ \\
\hline GS 60 & $33.3 \mathrm{~b}$ & $59.7 b$ & $82.1 \mathrm{a}$ & $14.9 \mathrm{~b}$ \\
\hline GS 82 & $87.1 \mathrm{a}$ & $79.7 \mathrm{a}$ & $91.5 \mathrm{a}$ & $37.6 \mathrm{a}$ \\
\hline \multicolumn{5}{|l|}{ Fungicide } \\
\hline With fungicide & $33.9 \mathrm{~b}$ & $57.0 \mathrm{a}$ & $72.7 \mathrm{a}$ & $26.1 \mathrm{a}$ \\
\hline Without fungicide & $55.7 \mathrm{a}$ & $48.1 \mathrm{a}$ & $70.0 \mathrm{a}$ & $17.3 \mathrm{a}$ \\
\hline
\end{tabular}

Mean values followed by the same letter in the same column among growth stages and between fungicidal treatments, are not statistically significant, LSD $(\mathrm{p}=0.05)$ 
Table 3. Mean values for arbuscules and AMF spores on a wheat crop with and without fungicide at three growth stages

\begin{tabular}{lcccccc}
\hline & \multicolumn{3}{c}{ Arbuscules } & \multicolumn{3}{c}{ Total spores } \\
\cline { 2 - 7 } \multicolumn{1}{c}{ Fungicides } & GS 31 & GS 60 & GS 82 & GS 31 & GS 60 & GS 82 \\
\hline With fungicide & $6.9 \mathrm{a}$ & $50.0 \mathrm{a}$ & $5.0 \mathrm{a}$ & $43.3 \mathrm{a}$ & $27.3 \mathrm{a}$ & $76.3 \mathrm{a}$ \\
Without fungicide & $3.3 \mathrm{a}$ & $30.6 \mathrm{~b}$ & $5.0 \mathrm{a}$ & $52.0 \mathrm{a}$ & $40.7 \mathrm{a}$ & $41.3 \mathrm{~b}$ \\
\hline
\end{tabular}

AMF - arbuscular-mycorrhizal fungi; GS - growth stage

Mean values followed by the same letter in the same column are not statistically significant, LSD $(p=0.05)$

Table 4. Analysis of variance for the number of spores belonging to three Glomeromycota morphotypes (glomoid, acaulosporoid, and gigasporoid) on a wheat crop with and without fungicide at three growth stages

\begin{tabular}{lccc}
\hline \multicolumn{1}{c}{ Source of variation } & $\mathrm{df}$ & Mean squares & $\mathrm{p}>\mathrm{F}^{*}$ \\
\hline Morphotype & 2 & 5622.72 & $<.001$ \\
Growth stage & 2 & 309.39 & 0.003 \\
Fungicide & 1 & 28.17 & 0.433 \\
Morphotype $\times$ growth stage & 4 & 145.28 & 0.023 \\
Morphotype $\times$ fungicide & 2 & 13.39 & 0.743 \\
Growth stage $\times$ fungicide & 2 & 355.39 & 0.001 \\
Morphotype $\times$ growth stage $\times$ fungicide & 4 & 143.61 & 0.024 \\
Residual & 34 & 44.70 & - \\
Total & 53 & - & - \\
\hline
\end{tabular}

*probability level, Fisher test

Table 5. Mean values for the number of spores belonging to three Glomeromycota morphotypes on a wheat crop with and without fungicide at three growth stages

\begin{tabular}{lccccc}
\hline $\begin{array}{c}\text { Glomeromycota } \\
\text { morphotypes }\end{array}$ & Fungicides & GS 31 & GS 60 & GS 82 & $\begin{array}{c}\text { Average } \\
\text { morphotypes }\end{array}$ \\
\hline Glomoid & with fungicide & $33.33 \mathrm{a}$ & $22.00 \mathrm{a}$ & $55.00 \mathrm{a}$ & $35.17 \mathrm{a}$ \\
& without fungicide & $42.67 \mathrm{a}$ & $28.00 \mathrm{a}$ & $30.00 \mathrm{~b}$ & $10.89 \mathrm{~b}$ \\
Acaulosporoid & with fungicide & $8.67 \mathrm{a}$ & $5.33 \mathrm{a}$ & $20.67 \mathrm{a}$ & $10.67 \mathrm{a}$ \\
Gigasporoid & without fungicide & $8.00 \mathrm{a}$ & $12.00 \mathrm{a}$ & $0.67 \mathrm{a}$ & $0.78 \mathrm{c}$ \\
& with fungicide & $1.33 \mathrm{a}$ & $0.00 \mathrm{a}$ & $0.67 \mathrm{a}$ & \\
\hline
\end{tabular}

Mean values followed by the same letter in the same column within the same morphotype are not statistically significant, $\operatorname{LSD}(p=0.05)$

the lack of effect on microorganisms in the root zone by the foliar application of those compounds. Moreover, triazoles such as tebuconazole act as inhibitors of the biosynthesis of ergosterol, a major component of fungal membranes. The relative amounts of ergosterol in AMF, however, are low in comparison with the concentrations present in the tissues of other groups of true fungi (Schmitz et al. 1992; Frey et al. 1994). To achieve significant effects on AMF, high dosages or repeated applications of ergosterol inhibitors would be necessary (Kjoller and Rosendahl 2000).

Since AMF exhibit an absolute dependence on the carbon resources provided by the plant, a severe foliar disease as exemplified in this experiment, may generate fluctuations in carbon availability. Mycorrhizal development in turn, would be strongly affected. A reduction in photosynthesis under the influence of $M$. graminicola would be expected to lead to a decrease in the carbon supply to the roots and thus negatively affect the development of mycorrhizal associations.
Significant differences were found among the morphotypes and also for the two-way interactions morphotype $x$ growth stage and growth stage $\times$ fungicide as well as for the three-way interaction morphotype $\times$ growth stage $\times$ fungicide (Table 4). The number of glomoid spores was higher than those belonging to the acaulosporoid and gigasporoid morphotypes (Table 5), whose distribution is consistent with other studies on agricultural systems in the same area (Schalamuk et al. 2006; Schalamuk and Cabello 2010). At GS 82, the spores belonging to the glomoid morphotype significantly increased with the application of fungicide. The acaulosporoid tended to increase as well, though not significantly so. In contrast, the number of gigasporoid spores was not affected by fungicide application.

Arbuscular mycorrhizal fungi have been classified within the classic life-history strategies ' $r-K$ ' on the basis of sporulation traits (De Souza et al. 2005; Ijdo et al. 2010; Verbruggen and Kiers 2010). While the AMF of the Gigasporaceae (with the gigasporoid morphotype) produce few and large spores within a long life cycle, and tend 
to resemble $K$-strategists, the AMF of the Glomeraceae (with the glomoid morphotype) display opportunistic behaviour, such as a rapid colonization and production of many small spores, typical of $r$-strategists (Denison and Kiers 2011). Ijdo et al. (2010) found that, since AMF exhibit an obligate dependence on plant carbon, the fluctuations in the availability of that element produced by defoliation, can differentially affect AMF with contrasting lifehistory strategies. Those authors found that Glomus intraradices, of the glomoid morphotype renamed Rhizophagus intraradices by Schüßler and Walker (2010) modulated spore production directly in accordance with carbon availability. A direct investment in reproduction as would be expected for an $r$-strategist was shown. Whereas Dentiscutata reticulata, of the gigasporoid morphotype, was not affected after a single defoliation and thus showed a marked resistance to fluctuating carbon levels. In the present study, the higher glomoid spore number found after fungicide treatment involving a greater green leaf area and consequently more photosynthates reaching the roots is consistent with the findings by Ijdo et al. (2010). Thus, carbon fluctuations may affect glomoid and gigasporoid morphotypes in a different manner.

In conclusion, during AMF symbiosis, an alteration in green-leaf area, such as occurs during a severe foliar disease and/or its control by fungicides, may result in a shift in the AMF community to favour members belonging to the glomoid morphotype. Glomoid species have been previously considered as $r$-strategists. The present results demonstrated that the control of severe wheat infections by fungicides paradoxically enough can even positively affect the AMF present. This happens, for example, by selecting for glomeromycota morphotypes with the appropriate adaptive life-history strategies.

\section{Acknowledgements}

Dr. Donald F. Haggerty, a retired career investigator and native English speaker, edited the final version of the manuscript. We would like to thank H. Piorno and J.P. Llado for their technical help with the experiment.

\section{References}

Bever J.D., Schultz P.A., Pringle A., Morton J.B. 2001. Arbuscular mycorrhizal fungi: More diverse than meets the eye, and the ecological tale of why. Bioscience 51 (11): 923-931.

Błaszkowski J., Kovács G.M., Balázs T. 2009. Glomus perpusillum, a new arbuscular mycorrhizal fungus. Mycologia 101 (2): 247-255.

Calonne M., Lounès-Hadj Sahraoui A., Campagnac E., Debiane D., Laruelle F., Grandmougin-Ferjani A., Fontaine J. 2012. Propiconazole inhibits the sterol $14 \alpha$-demethylase in Glomus irregulare like in phytopathogenic fungi. Chemosphere 87 (4): 376-383.

Campagnac E., Fontaine J., Lounès-Hadj Sahraoui A., Laruelle F., Durand R., Grandmougin-Ferjani A. 2008. Differential effects of fenpropimorph and fenhexamid, two sterol biosynthesis inhibitor fungicides, on arbuscular mycorrhizal development and sterol metabolism in carrot roots. Phytochemistry 69 (17): 2912-2919.

Campagnac E., Fontaine J., Lounès-Hadj Sahraoui A., Laruelle F., Durand R., Grandmougin-Ferjani A. 2009. Fenpropimorph slows down the sterol pathway and the development of the arbuscular mycorrhizal fungus Glomus intraradices. Mycorrhiza 19 (6): 365-374.

Chagnon P., Bradley R., Maherali H., Klironomos J. 2013. A traitbased framework to understand life history of mycorrhizal fungi. Trends Plant Sci. 18 (9): 484-491.

Denison F.R., Kiers E.T. 2011. Life histories of symbiotic rhizobia and mycorrhizal fungi. Curr. Biol. 21 (18): 775-785.

De Souza F.A., Declerck S., Smit E., Kowalchuk G.A. 2005. Morphological, ontogenetic and molecular characterization of Scutellospora reticulata (Glomeromycota). Mycol. Res. 109 (6): 697-706.

Dick R.P., Thomas D.R., Turco R.F. 1996. Standarized methods, sampling and sampling treatment. p. 107-121. In: "Methods for Assessing Soil Quality" (J.W. Doran, A.J. Jones, eds.). Soil Science Society of America, Madison, Wisconsin, $410 \mathrm{pp}$.

Diedhiou P.M., Oerke E.C., Dehne H.W. 2004. Effect of the strobilurin fungicides azoxystrobin and kresoximmethyl on arbuscular mycorrhizal. J. Plant Dis. Prot. 111 (6): 545-556.

Eyal Z., Scharen A.L., Huffman M.D., Prescott J.M. 1985. Global insights into virulence frequencies of Mycosphaerella graminicola. Phytopathology 75 (12): 1456-1462.

Eyal Z., Scharen A.L., Prescott J.M., Van Ginkel M. 1987. The Septoria Diseases of Wheat: Concepts and Methods of Disease Management. CIMMYT, Mexico, DF, 52 pp.

Franke-Snyder M., Douds D.D.J., Galvez L., Philips J.G., Wagoner P., Drinkwater L., Morton J.B. 2001. Diversity of communities of arbuscular mycorrhizal (AM) fungi present in conventional versus low-input agricultural sites in eastern Pennsylvania. Appl. Soil Ecol. 16 (1): 35-48.

Frey B., Vilarino A., Schuepp H., Arines J. 1994. Chitin and ergosterol content of extraradical and intraradical mycelium of the vesicular-arbuscular mycorrhizal fungus Glomus intraradices. Soil Biol. Biochem. 26 (6): 711-717.

GenStat Release 12.1 ( PC/Windows XP). 2009. VSN International Ltd.

Gerdemann J.W., Nicolson T.H. 1963. Spores of mycorrhizal Endogone species extracted from soil by wet sieving and decanting. Trans. Br. Mycol. Soc. 46 (2): 235-244.

Giovannetti M., Turrini A., Strani P., Sbrana C., Avio L., Pietrangeli B. 2006. Mycorrhizal fungi in ecotoxicological studies: soil impact of fungicides, insecticides and herbicides. Prevention Today 2 (1-2): 47-61.

Hodge A., Helgason T., Fitter A.H. 2010. Nutritional ecology of arbuscular mycorrhizal fungi. Fungal Ecol. 3 (4): 267-273.

Homdork S., Fehrmann H., Beck R. 2000. Effects of field application of tebuconazole on yield, yield components and the mycotoxin content of Fusarium-infected wheat grain. J. Phytopathol. 148 (1): 1-6.

Ijdo M., Schtickzelle N., Cranenbrouck S., Declerck S. 2010. Do arbuscular mycorrhizal fungi with contrasting life-history strategies differ in their responses to repeated defoliation? FEMS Microbiol. Ecol. 72 (1): 114-122.

Kjoller R., Rosendahl S. 2000. Effects of fungicides on arbuscular mycorrhizal fungi: differential responses in alkaline phos- 
phatase activity of external and internal hyphae. Biol. Fertil. Soils 31 (5): 361-365.

Koske R.E., Tessier B. 1983. A convenient, permanent slide mounting medium. Mycol. Soc. Am. Newsl. 34 (2): 59.

Land S., von Alten H., Schonbeck F. 1993. The influence of host plant, nitrogen fertilization and fungicide application on the abundance and seasonal dynamics of vesiculararbuscular mycorrhizal fungi in arable soils of northern Germany. Mycorrhiza 2 (4): 157-166.

Lovelock C.E., Andersen K., Morton J.B. 2003. Arbuscular mycorrhizal communities in tropical forests are affected by host tree species and environment. Oecologia 135 (2): 268-279.

McGonigle T.P., Miller M.H., Evans D.G., Fairchild G.L., Swan J.A. 1990. A new method which gives an objective measure of colonization of roots by vesicular - arbuscular mycorrhizal fungi. New Phytol. 115 (3): 495-501.

Mohammad M.J., Pan W.L., Kennedy A.C. 1998. Seasonal mycorrhizal colonization of winter wheat and its effect on wheat growth under dryland field conditions. Mycorrhiza 8 (3): 139-144.

Mojerlou S., Safaie N., Alizadeh A., Khelghatibana F. 2009. Measuring and modeling crop loss of wheat caused by Septoria leaf blotch in seven cultivars and lines in Iran. J. Plant Prot. Res. 49 (3): 257-262.

Morton J.B., Bentivenga S.P., Wheeler W.W. 1993. Germ plasm in the International Collection of Arbuscular and Vesiculararbuscular Mycorrhizal Fungi (INVAM) and procedures for culture development, documentation and storage. Mycotaxon 48 (2): 491-528.

Oehl F., Sieverding E., Palenzuela J., Ineichen K., Alves da Silva G. 2011. Advances in Glomeromycota taxonomy and classification. IMA Fungus 2 (2): 191-199.

Parvartha Reddy P. 2013. Recent Advances in Crop Protection. Springer, India, $278 \mathrm{pp}$.

Phillips J.M., Hayman D.S. 1970. Improved procedures for clearing roots and staining parasitic and VA mycorrhizal fungi for rapid assessment of infection. Trans. Brit. Mycol. Soc. 55 (1): 158-161.

Pozo M.J., Verhage A., García-Andrade J., García J.M., AzcónAguilar C. 2009. Priming plant defense against pathogens by arbuscular mycorrhizal fungi. p. 123-136. In: "Mycorrhizas - Functional Processes and Ecological Impact" (C. Azcón-Aguilar, J.M. Barea, S. Gianinazzi, V. GianinazziPearson, eds.). Springer Verlag, Berlin, 372 pp.

Schalamuk S., Cabello M. 2010. Arbuscular mycorrhizal fungal propagules from tillage and no-tillage systems: possible effects on Glomeromycota diversity. Mycologia 102 (2): 261-268

Schalamuk S., Velázquez S., Chidichimo H., Cabello M. 2004. Effect of no-till and conventional tillage on mycorrhizal colonization in spring wheat. Bol. Soc. Argent. Bot. 39 (1-2): 13-20.

Schalamuk S., Velázquez S., Chidichimo H., Cabello M. 2006. Fungal spore diversity of arbuscular mycorrhizal fungi as- sociated with spring wheat: effect of tillage. Mycologia 98 (1): 22-28.

Schmitz O., Danneberg G., Hundeshagen B., Klingner A., Bothe H. 1992. Quantification of vesicular-arbuscular mycorrhiza by biochemical parameters. J. Plant Physiol. 139 (1): 106-114.

Schüßler A., Schwarzott D., Walker C. 2001. A new fungal phylum, the Glomeromycota: phylogeny and evolution. Mycol. Res. 105 (12): 1413-1421.

Schüßler A., Walker C. 2010. The Glomeromycota: a species list with new families and new genera. Edinburgh and Kew. The Royal Botanic Garden Kew, Botanische Staatssammlung Munich, and Oregon State University. http://www. amf-phylogeny.com [Accessed: October 21, 2013].

Schweiger P.F., Jakobsen I. 1998. Dose-response relationships between four pesticides and phosphorus uptake by hyphae of arbuscular mycorrhizas. Soil Biol. Biochem. 30 (10-11): 1415-1422.

Shaner G., Finney R.E. 1977. The effect of nitrogen fertilization on the expression of slow-mildewing resistance in Knox wheat. Phytopathology 67 (8): 1051-1056.

Sieverding E. 1991. Vesicular-Arbuscular Mycorrhiza Management in Tropical Agro-Ecosystem. Deutsche Gesellschaft für Technische Zusammenarbeit, Eschborn, 371 pp.

Simón M.R., Perelló A.E., Cordo C.A., Struik P.C. 2002. Influence of Septoria tritici on yield, yield components, and test weight of wheat under two nitrogen fertilization conditions. Crop Sci. 45 (6): 1974-1981.

Simón M.R., Cordo C.A., Perello A.E., Struik P.C. 2003. Influence of nitrogen supply on the susceptibility of wheat to Septoria tritici. J. Phytopathol. 151 (5): 283-289.

Smith S.E., Read D.J. 2008. Mycorrhizal Symbiosis. 3rd ed. Academic Press, London, 800 pp.

Verbruggen E., Kiers E.T. 2010. Evolutionary ecology of mycorrhizal functional diversity in agricultural systems. Evol. Appl. 3 (5-6): 547-560.

Verbruggen E., Veresoglou S.D., Anderson I.C., Caruso T., Hammer E.C., Kohler J., Rillig M.C. 2013. Arbuscular mycorrhizal fungi-short-term liability but long-term benefits for soil carbon storage? New Phytol. 197 (2): 366-368.

Walker C., Mize W., McNabb H.S. 1982. Populations of endogonaceous fungi at two populations in central Iowa. Can. J. Bot. 60 (12): 2518-2529.

Whipps J.M. 2004. Prospects and limitations for mycorrhizas in biocontrol of root pathogens Can. J. Bot. 82 (8): 1198-1227.

Zadoks J.C., Chang T., Konzak C.F. 1974. A decimal code for the growth stages of cereals. Weed Res. 14 (6): 415-421.

Zocco D., Fontaine J., Lozanova E., Renard L., Bivort C., Durand R., Grandmougin-Ferjani A., Declerck S. 2008. Influence of two sterol biosynthesis inhibitor fungicides (fenpropimorph and fenhexamid) on the development of an arbuscular mycorrhizal fungus. Mycol. Res. 112 (5): 592-601. 